A peer reviewed open access journal indexed in NepJol; ISSN 2542-2596

Published by Molung Foundation, Kathmandu, Nepal

Article History: Received on13 March 2021; Accepted on 29 May 2021

DOI: $\underline{\text { https://doi.org/10.3126/mef.v11i0.37852 }}$

\title{
Modernization in Medical Practices in Rural Nepal: An Ethnographic Study of Hyolmos
}

\author{
Ram Hari Dhakal \\ Tribhuvan University, Ratna Rajya Laxmi Campus, Nepal
}

\begin{abstract}
Author Note
Dr. Ram Hari Dhakal is the faculty at the Department of Anthropology at Ratna Rajya Laxmi Campus, Tribhuvan University, Nepal. He is also involved in a number of research projects and has written several research articles on various socio-cultural issues. Email: rhdhaka130@gmail.com
\end{abstract}




\begin{abstract}
This article attempts to investigate the modern medical practices and the major factors triggering the changes in views, attitudes, and practices among the Hyolmos, an indigenous people residing in high hill region, Helambu, the northeast of Sindhupalchok, central Nepal. This ethnographic study with the key informants' interview, participant observation and household census was employed during a year-long fieldwork. The collected data were thematically analyzed and interpreted. The finding shows that the major triggering factors bringing such changes are education, communication, and transportation that increased awareness among the people for choosing alternative opportunities. Tourism and foreign employment raised the economic level that created better financial options for treatment. Conservation of forest was limited to the performance of herbalists and Amchis. To some extent, inter-caste marriage practice and the urbanization process also increased awareness about the use of western medicine.
\end{abstract}

Keywords: allopathic practice, change, education, modernity, tourism, transportation 


\section{Modernization in Medical Practices in Rural Nepal: An Ethnographic Study of Hyolmos}

Modernity has brought great changes in many aspects of life including medical practices. Considering health as one of the most important concerns in life, peoples' practices are transforming in modern medicine along with the modernity. Among the medical practices, allopathic practice is more popular along with the development, education and modernity (Pigg, 1995, 1996) and it is preferred more for the treatment of any illnesses even in rural areas where there is easy access to health posts.

Despite the barriers, changes occur in society. Sometimes we observe revolutionary changes and sometimes changes occur slowly. In the process of social change, medical and healing practices also cannot remain unchanged. Many changes are observed among Hyolmo people regarding their medical choices and different healing and medical practices. The drastic changes have clearly been examined since 1980s. But those changes in medical practices have not yet been assessed through in-depth study. The purpose of the paper is thus to investigate the present conditions, different changes in healing and medical traditions, healing procedures, and the factors of changes on medical practices among the Hyolmos.

Many factors have played significant role for the changes in their entire lifestyle in recent decades. Medical practice also could not remain far from those changes. In this paper, the changes related practices that tend to go with modernization and factors contributing to those changes are presented and analyzed.

Ethnographic fieldwork was carried out in the Hyolmo community for one year in $2015 / 16$ by using a number of data-gathering techniques such as key informants' interview, participant observation and household census. Local teachers, nurse of local health post, political and social leaders, and elderly people 
were taken as key informants in this study. Interviews were carried out with local health service consumers. Necessary data were gathered through observation of health seeking behaviour and their destination. Socio-demographic data had been collected using household census. Data gathered were thematically analyzed and interpreted, which are presented in the following subsections.

Feierman (1981), Frackenberg and Leeson (1976), and Young (1981) describe the systems model to analyze the impact of social forces on the search for health care. This model, according to Janzen (1978), requires two levels of analysis: one at the micro level (incorporating perceptions about an illness, its prevalence, and efforts to diagnose, prevent, and cure) and the other at the macro level (incorporating information about large-scale social entities such as health institutions, economic and political systems that dictate access to health care). In this study, I have used both levels of analysis.

\section{Conceptual Framework}

Medical system is an integral part of all cultures. It encompasses the totality of health beliefs, knowledge, skills, and practices of a cultural group. It incorporates all clinical and non-clinical activities, formal and informal institutions, and other activities that are even indirectly connected with illness in a community. The conceptual framework depicted through Figure 1 was developed to explore the changes in health seeking priorities and their causes among Hyolmos.

The framework shows that the traditional healing practices such as faith healers (Bhombo), herbal, Aamchi (Himalayan doctor) and home remedies are changing nowadays toward allopathic western medicine due to the factors like education, transportation, communication, foreign employment, tourism, trade, economic prosperity, inter-caste marriage practice, link with city, establishment of National Park and Health post etc. 


\section{Figure 1}

Conceptual Framework for Changes in Medical Practices and their Factors

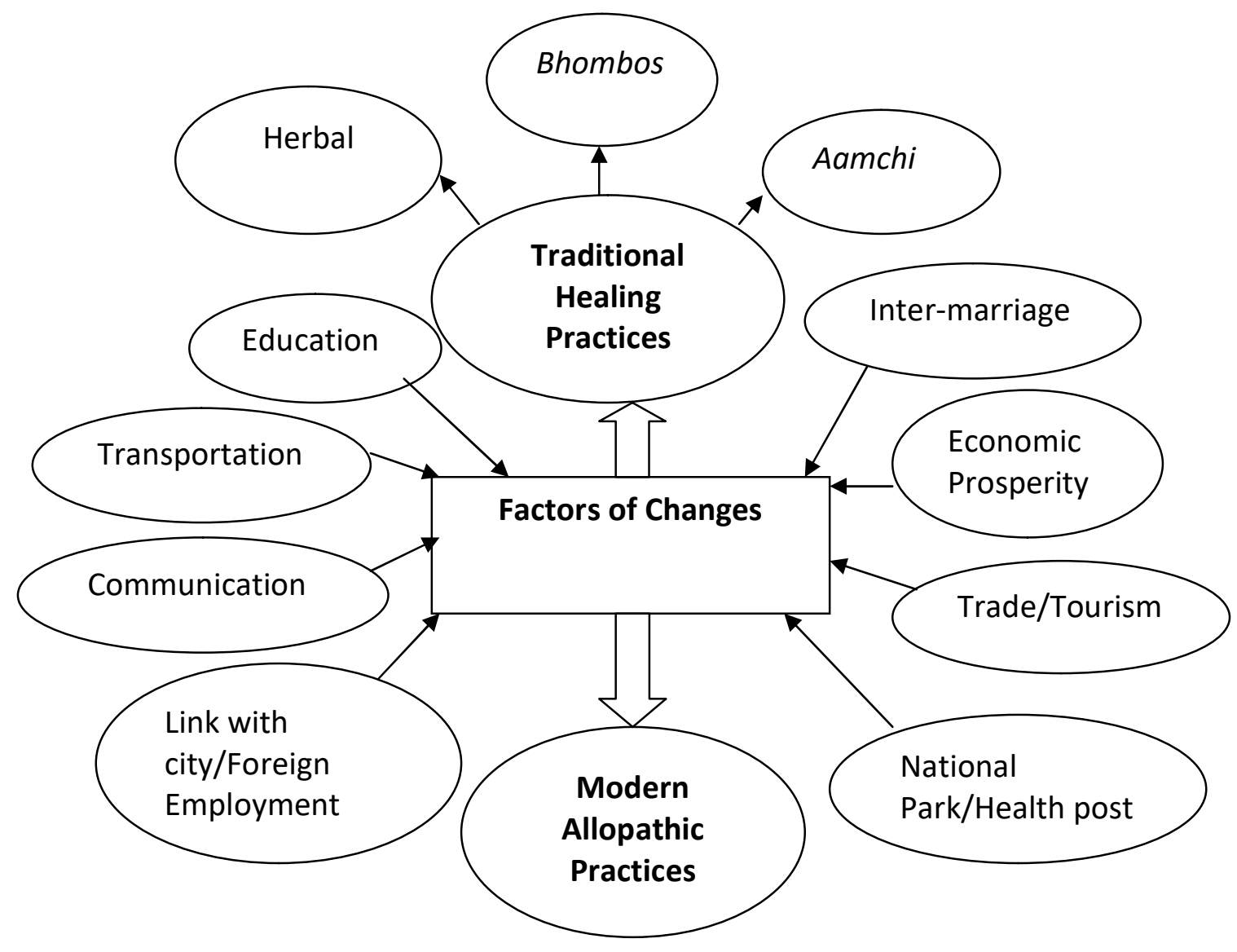

\section{Analysis and Discussion of Empirical Findings}

\section{Melamchi Ghyang: A Timeline}

Melamchi Ghyang is a rural village of Helambu Rural Municipality,

Sindhupalchok. It has its own history based on local events, and it is influenced by some national events too. These events are associated with medical/healing choice and their transformation as shown below in Table 1. 


\section{Table 1}

Melamchi Ghyang in Timeline

Dates Major Events Major Changes

(A.D.)

\begin{tabular}{|c|c|c|}
\hline $1950 \mathrm{~s}$ & $\begin{array}{l}\text { People went to work in } \\
\text { Burma, Assam and Sikkim }\end{array}$ & $\begin{array}{l}\text { After the contact with outside cultures } \\
\text { through out-migration; western } \\
\text { medical practice began gradually }\end{array}$ \\
\hline $1960 \mathrm{~s}$ & $\begin{array}{l}\text { Circular migration to } \\
\text { different cities of India } \\
\text { accelerated }\end{array}$ & $\begin{array}{l}\text { Increase in awareness, allopathic } \\
\text { medicine introduced, increase in } \\
\text { economic well being }\end{array}$ \\
\hline 1976 & $\begin{array}{l}\text { Langtang National Park } \\
\text { established }\end{array}$ & $\begin{array}{l}\text { Rumor of capturing pastureland by the } \\
\text { expansion of national park and people } \\
\text { started to shift in other works }\end{array}$ \\
\hline $1980 \mathrm{~s}$ & $\begin{array}{l}\text { Chauri production started in } \\
\text { local shed }\end{array}$ & $\begin{array}{l}\text { End of buying chauris in expensive } \\
\text { rate from upper Rasuwa, increase } \\
\text { economic strength }\end{array}$ \\
\hline 1982 & $\begin{array}{l}\text { Death of the third Chiniya } \\
\text { Lama }\end{array}$ & Unofficial end of the era of feudalism \\
\hline 1986 & $\begin{array}{l}\text { Jungle of Melamchi } \\
\text { Ghyang area incorporated } \\
\text { in National park }\end{array}$ & $\begin{array}{l}\text { Loss of autonomy on the control of } \\
\text { jungle resources by the villagers, } \\
\text { control in herbs collection }\end{array}$ \\
\hline 1987 & $\begin{array}{l}\text { Langtang Trekking route of } \\
\text { Sundarijal, Gosainkunda, } \\
\text { Melamchi Ghyang opened }\end{array}$ & $\begin{array}{l}\text { Tourism accelerated, increase in } \\
\text { allopathic medicine, economic } \\
\text { strength }\end{array}$ \\
\hline 1989 & $\begin{array}{l}\text { School established in local } \\
\text { area }\end{array}$ & $\begin{array}{l}\text { Helped to raise awareness in every } \\
\text { sector including health and hygiene, } \\
\text { socialization of children, raised }\end{array}$ \\
\hline
\end{tabular}


1990

1990

$1990 \mathrm{~s}$

2000 s

2005

2007/8 Telephone and cell phone service expanded

2010/11 Disc home TV channel system began

2011 Melamchi FM was established in the local area

2011 Establishment of health post

2012 Link with road transport

2013 Local high school started $10+2$ class allopathic practices

Raised awareness in politics, increased link with other non-Hyolmos Increase in the facilities of the means of communication

Awareness on HIV/AIDS and sexually transmitted diseases

Freedom on land using, economic strength

Health facilities started, local school got support

Easy communication with relatives living in city and Bazaar area, information about the availability of doctors in the Health Centers Access to different channels and television programs Health program started to broadcast in radio, awareness increased Facilities of modern health service, allopathic medicine users accelerated Offered different facilities such as food and medicine supply Access of higher education locally

Source: Fieldwork, 2015 
This has happened the past as well. Talking about the medical practice in the past, Bishop (1998) states:

In 1970-71, residents of Melamchi only occasionally sought medical advice in Kathmandu. Seeking medical treatment from hospital in the city means they needed time to be away from the village and work, the necessity of cash payment and lack of familiarity with the Nepali language. This meant most people having illnesses were dealt with in the village. The distance and terrain were other impediments. Without road and helicopters, people had to be carried on the back of others which was extremely uncomfortable for everyone involved... General people used home remedies. (p. 128)

\section{Transformation in medical practices}

Despite difficulties and uncertainties of the past there are now many changes which have brought about remarkable transformation in medical practices. They are discussed below.

\section{Education}

Education is the key factor to change the society. Education gives awareness, and conscious people have different attitudes toward medical choice. Since the establishment of Melamchi Ghyang School in 1989, the literacy rate in the area changed from nearly 0 to 62 percent. Among the above six years aged population, 8.18 percent are grade 10 passed and 6.34 percent have passed up to secondary (grade 12 ) level. Five males ( 2 percent) have successfully completed bachelor's level too. Analyzing on the basis of sex, 74.5 percent males and 48.74 percent females are literate now (Fieldwork, 2015). Adult literacy classes are going on continuously for four years. These classes have also contributed to increase literacy rate in the area. 
Along with the increasing number of people with formal education, medical choices and priority are also changing. Mani Prasad Adhikari, the head teacher of Pema Chhyoling Lower Secondary School, Nakote, shared:

We refer first to local health post and then to Melamchi Hospital or to the hospitals of Kathmandu, depending on the seriousness of patients, but we never refer to Dhami/Jhankris (faith healers). In the past, local people were ignorant and consumed alcohol even in the case of typhoid fever; as a result, many of them lost their lives. But now the situation has changed due to school education.

Some youths who study higher education in Kathmandu also have changed their family members' healing destination. The families, who depended on local shamans in the past, have started to go to health post or hospital for the purpose seeking health now. Education has contributed to decrease the status of Dhami/Jhankris and their followers. It has also helped to decrease several superstitious beliefs such as the tradition of sacrificing animals to appease what they called disease causing deities.

\section{Transportation}

Timbu, the lower Helambu, was connected with road transport a decade ago. There is public bus facility regularly in all seasons. It is connected by graveled road because it is near the tunnel of Melamchi Drinking Water Supply Project for Kathmandu Valley. Melamchi Ghyang is about $75 \mathrm{~km}$ north-east from Kathmandu, connected by agricultural road. The place was connected by the road in 2011 but cannot run transport regularly due to the worse road condition and lack of bridge over the Melamchi River. Thus, bus facilities are limited only to winter season. Recently, the queue of public bus started in 2015, but this road transport is less reliable.

Facility of road transport has started to bring change in their lifestyle. About 21 percent households use LP gas instead of firewood as fuel for cooking. 
It has decreased the smoke of their fireplace and supported healthy life. Transportation supported to the supply of allopathic medicine in the local health post and food supply to villagers from the market. It has made it easy to go to city hospitals or use ambulance, which brought change in the locales' medical practices.

\section{Communication}

All the households use electricity in Melamchi Ghyang. It had been supplied since 1990 from the small-scale hydroelectricity project of Phadung Khola, established in 1986. It supported the communication system. Now this hydroelectricity project has stopped but the main grid of electricity is connected. Most of the households have televisions along with Dish Home, and it has contributed to choose medical options on locales due to the information about treatment systems. Thus, they have become familiar with the modern practices.

There are three FM radio stations around: Melamchi FM, Sindhu FM and Sunkoshi FM. Their broadcasts are easily heard in Hyolmo region. They also broadcast health awareness programs and advertisement of hospitals. Namobuddha FM, Kabhrepalanchok and some other FM broadcasts with Kathmandu station are also heard. Some informants claimed that they are influenced by radio programs.

Communications explicitly increase people's determination to modify habits detrimental to their health (Bandura 1990). Means of communication changes health habits and instruct them the way of health behaviour. These means of communication have direct and indirect impacts in health sector.

Hyolmos were found having communication services like internet, Telephone and cell phone and they have almost regular talk with their family members who live in Kathmandu or abroad. The referral cause, knowledge about health service, and information about the availability of healers have changed the medical choice toward faster service along with the choice of better alternatives. 


\section{Foreign Employment}

Human mobilization for employment across border is increasing. Foreign employment has played significant role in the health seeking behaviour among Hyolmos in both health consciousness and economic efficiency.

The main occupation of Hyolmos three decades ago was transhumant herding. Due to their hard life, they gradually shifted to occupation other than transhumant herding. As a result, their economic status elevated. Now their major source of income is foreign employment. Hyolmos have gone to mainly India for work, and some of them are working in US, UK, Israel, Korea, Hong Kong, Canada, Finland, Dubai, Kuwait, etc. Among the foreign employed locales, the member of about 46 percent households are in India, and more than 8 percent are in US and 2 to 5 percent are scattered in other states (Fieldwork 2015). Bishop (1998) applies the term 'circular migration' to this process of migration of Hyolmos, mainly the migration for short period to work in India and to return. Foreign employment has enhanced their economic level, which has influenced the better choice of healers in advanced hospitals. Generally, persons who go abroad have adopted allopathic practices due to economic strength. A 53year-old local male informant, Kami Sherpa shared that he has a son in Korea, the next son is in UK and daughter-in-law is in Hong Kong. He used to go to Bhombos to heal in the past when all his family members were with him in village. Now his medical choice has been shifted to allopathic practice.

Before the establishment of health post in Helambu, the people who worked in India seasonally, used to bring normal allopathic medicine in the village. Generally they go to India after the celebration of Lhosar (in February) and come back in September, October. They became familiar with allopathic medicine in India and also brought some medicines when they returned to their home. Many villagers claim that the beginning of western medicine is by Indian returnee villagers. The villagers have been working in different places of India 
such as Laddakh, Himanchal, Arunanchal, and Assam even today. When I was in Melamchi Ghyang in January and February, almost all the households were full of family members who came to celebrate Sonam Lhosar, and when I went again in June or July, there were very few people in most of the households, and some of the houses were empty.

\section{Tourism}

Helambu lies in the Langtang trekking route. It is one of the oldest trekking routes in Nepal, developed in 1970s. Tourism has made the villagers prosperous economically on one hand, and it has introduced western medicine on the other. Tourists have contributed to change the villagers' medical behavior towards allopathic practice. Some tourists used to bring normal medicine and give to the villagers if needed till the last decade of twentieth century.

Melamchi Ghyang is no more isolated due to the expansion of transport and communication. Many Nepalis also go there for trekking, pilgrims, tour and business. They also have contributed to change the local people's medical practices.

\section{Trade Route}

Helambu is located in the middle of a triangle of the trade route that links Kathmandu, Nyenam and Kyirong. In Kathmandu valley the two main settlements, namely Swoyambhu and Bouddha, can respectively be seen as the end points of the Kyirong and Nyenam trade route to Kathmandu. Until two generations ago, people travelled from Helambu to the east via Thangpal, Gunsa and Golchhe, a journey of two to three days for the salt/grain trade. In the past, Hyolmos travelled through this route with rice, cloth, peppers and thread, and returned not only with salt but with wool, blanket and sheep for sale to Hindu people for the festival of Dashain (Clarke 1980). A local teacher of the high school, claimed, "The native Rongwa (low land people) used to come in Melamchi Ghyang since long ago as it is a route of Kyirong to take salt. Timure, 
the border of Rasuwa and Tibet, can be reached through Melamchi Ghyang via Semchhelang pass which has influenced every aspect of life including medical practices". Nowadays these routes are not in use.

\section{Economic Prosperity}

In Melamchi, herders faced economic constraints from the factors of geography and history. Melamchi herders were isolated from services and information. They had no access to veterinary medicine and clinic (Bishop 1998). Due to their hard herding life, they gradually shifted to the occupations other than transhumant herding. As a result, their economic status elevated. Now very limited transhumant herders are there. This was once the lifestyle of every Hyolmos.

Economic status seems to be the major factor for medical choice among the Hyolmo people. The major income source was transhumant herding till 1970s. Now tourism-related business such as hotels and lodges, going abroad to work, changing land ownership from Guthi to Raikar (private), employment in local area etc. have increased their economic level and has increased the choice of medical alternatives along with their material culture.

Due to the affordability of villagers to treat in city hospitals, economic growth has contributed to increase the tendency towards allopathic medical practice and also has accelerated the healing procedure.

\section{Establishment of Health Post and Hospital}

After the establishment of health post in 2011 in Melamchi Ghyang by the support of Community Action Nepal (CAN), the locals' first choice has become health post in health problem. About 47 percent household heads share that they go to health post first for the basic health facilities for themselves and for their family members. Common health problems like common cold, diarrhea, cough, high blood pressure, vaccination, pregnancy test, delivery, fever, etc., are treated in health post. There is a staff nurse to facilitate the locals. Further treatment of 
patient has been made possible from the occasional visit of doctors. The locals who fully depended on traditional healers (Bhombos) in the past have started to go to health post now. The reason to choose health post is education and awareness on the one hand and its reliable facilities and cheap cost of health post service on the other hand. People get all the facilities of health post throughout the year when they become member of health post by paying Rs. 100 per person annually. Medicines are also available free of cost.

Rinki Sherpa, the staff nurse of the local health post (Ninja Rinjen Community Health Service centre), claims, "All people come to take service in Health Post except for Bhombo and Lama themselves. Even the family members of Bhombo and Lama are facilitated by HP. The local people are also satisfied with the facilities of HP. They expect a modern hospital in local area".

The villagers also prefer health post due to its location, as it is situated in the centre of village. People go there first in every minor and major case. Even the people who have indigenous healing knowledge began to go to health post.

\section{Link with Kathmandu}

Though Melamchi Ghyang is a rural area, many villagers have started to follow modern medical practices due to the link with Kathmandu. The villagers have the trend of using allopathic medicine now: 50 percent of the locals have home and 27.08 percent of them have land in Kathmandu. Rests of the villagers also visit Kathmandu frequently as they have relatives, or for business or their children as the students have gone to Kathmandu for higher studies.

The people of Melamchi Ghyang have a strong historical link with Kathmandu. The Bouddha Ghyang Guthi, Kathmandu and Melamchi Ghyang Guthi, Melamchi Ghyang both were once under the control of Chiniya Lama's generation who lived in Bouddha and frequently visited to Melamchi Ghyang to see things. The link with Kathmandu has made them familiar with modern medical practices. They have more medical options and are aware of more 
possibilities of choice of various medical practices. The modern medical practice is the most important one.

\section{Inter-caste Marriage Practice}

Inter-caste/ethnic marriage was strictly prohibited among Hyolmos in Melamchi Ghyang till three decades back. They used to get married with only Hyolmos but of a different clan. There are five clans under Hyolmos in Melamchi Ghyang: Ghale, Syangba, Jhhyaba, Yoba and Lama. But now inter-caste marriage is common among them: 65.7 percent $\mathrm{HH}$ heads prioritize marriage based on prior love because they claim that the partner can understand each other in this kind of marriage; $82.29 \mathrm{HH}$ heads accepted that inter-marriage is common in their community (Fieldwork, 2015).

Inter-caste marriage practice began since 1980s when Hyolmo youths started to work abroad and went to Kathmandu for business and higher studies. This practice accelerated with the development of transportation and communication. But Hyolmos still do not accept the marriage with Dalit (untouchables) castes.

Marriage is one of the major means of diffusion of culture. Medical practice is also a cultural part; we can observe some changes in medical choice due to inter-caste marriage. Sometimes the bride brings new healing knowledge of her culture and tends to apply them in new home so that some changes in traditional herbal and home remedies are found. The economic support and the referral cause which is made by the relatives established after inter-marriage; they get alternative opportunities in medical practice.

\section{Langtang National Park and Community Forest Users Group}

Langtang National Park was established in 1976. It covers three districts: Rasuwa, Nuwakot and Sindhupalchok. Melamchi Ghyang was incorporated in the park only in 1986. Helambu is a VDC adjoining Lantang National Park, and Melamchi Ghyang village is very near the park, less than $1 \mathrm{~km}$. The villagers are 
not allowed to enter the jungle area to collect forest products as it is the protected area. For the systematic use of forest products, a community forest users group (Dhupu Samudayik Ban Samittee) is formed. The national park and community forest users group have controlled the use of forest products. A limited amount of firewood and fodders can be collected and used systematically, but herbal products are strictly prohibited to collect.

There are 15 forest types and more than 1,000 species of flowering plants and ferns and medicinal herbs within the national park (Shrestha 1985). Due to the strict policy of national park and forest users group, mass production and business of the herbal products is not possible. The local herbalists are feeling difficult to get medicinal herbs. There are no skillful herbalists by profession, but the traditional herbalists who use the herbs to treat the family and community are also feeling problem.

Aamchi also uses herbal plants for treatment, but the area where he lives is not incorporated under the National Park when the people refused to be included in 1986 (Bishop 1998). Now, use of herbal medicine is limited because of their less effective medicine. When the villagers want more effective medicine for prompt recovery, they use allopathic medicine.

\section{Summary and Conclusion}

Hyolmos' medical choices are changing for around three to four decades. Their choices, priority, procedure and even belief system are found changed. Several factors have been playing significant role for such change. School and adult literacy classes have made the locals aware in their health condition and healing process as education and awareness is the prime factor to bring about such changes. Informants with formal education have given high preference to allopathic practice. Similarly, Hyolmos' economic prosperity made it possible to choose the best medical alternatives. They are economically better and have access to hospitals and treatment procedures. In recent decades, Hyolmos have 
gone abroad to work and this has influenced local peoples' medical choices. Now Melamchi Ghyang is facilitated with transport and communication, which brought remarkable changes in medication practice. The locals who depended fully on traditional healers in the past have started to go to Melamchi Hospital or Kathmandu now for better treatment. After the establishment of health post, locals' health behavior changed drastically as they prefer to use allopathic medicine as the first choice. The health post is giving health care at a low cost. The number of Dhami/Jhankris is decreasing and herbal practices are also declining along with the establishment of health post. Inter-caste marriage and the link with Kathmandu helped to bring Hyolmos in touch with the outer world. These practices have contributed to cultural exchange.

Establishment of national park and community forest users' group resulted in the decline of herbalist's profession. Tourism and political factors are the minor causes which brought change in Hyolmos' health-seeking behaviour. All these factors mainly changed the traditional medical choices into allopathic practice. Now allopathic medical practice is an established practice that many Hyolmos follow.

Medical practices change due to several factors. People's choices, priority, procedure and even belief system are changing due to global impact. Education and awareness brought by school and adult literacy classes is the prime factor for changes where educated people give high preference to allopathic practice. Economic prosperity has made possible to choose the best medical alternatives. Foreign workers have influenced local peoples' medical choices. The locals who depended fully on traditional healers in the past have started to go to city hospital for better treatment because of transport and communication facilities. Locales prefer to use allopathic medicine as the first choice from health post. The number of faith healers and herbal practitioners are declining along with establishment of health post. Inter-caste/ethnicity marriage and the link with city has helped touch 
with the outer world. Establishment of national park and community forest users' group has resulted in the decline of herbalist's profession. Change in the locales' life style from transhumant herding to modernity has brought a big change in medical practices. Consequently, decreasing ratio of transhumant herding has decreased herbal and self-medication practices. Tourism and political factors are the minor causes of changes they also have contributed to decrease the followers of traditional healers and superstitious beliefs. All these factors mainly changed the traditional medical choices into allopathic practice. 


\section{References}

Bandura, A. (1990). Perceived self-efficacy in the exercise of control over AIDS infection. Evaluation and Program Planning, 13, 9-17.

Bishop, N. (1998). Himalayan herders: Case studies in cultural anthropology. Harcourt Brace College Publishers.

Clarke, G. E. (1980). The temple and kinship among a Buddhist people of the Himalayas [Unpublished doctoral dissertation]. University of Oxford.

Feierman, S. (1981). Therapy as a system-in-action in north-eastern Tanzania. Social Science and Medicine, 15(B), 353-360. http://www.journals.elsevier.com/social-science-and-medicine/

Frackenberg, R., \& Leeson, J. (1976). Disease, illness and sickness: Social aspects of the choice of healer in a Lusaka Suburb. In J.B. Loudon (Ed.), Social anthropology and medicine (pp. 223-258). New York Academic Press.

Janzen, J. (1978). The comparative study of medical systems as changing social systems. Social Science and Medicine, 12 (B), 121-129. http://www.journals.elsevier.com/social-science-and-medicine

Pigg, S. L. (1995). The social symbolism of healing in Nepal. Ethnology, 34 (1), 17-36. doi: $10.2307 / 3773861$

Pigg, S. L. (1996). The credible and the credulous: The question of "Villagers" Beliefs" in Nepal. Cultural Anthropology, 11(2), 160-201. doi:10.1525/can.1996.11.2.02a00020

Shrestha, C.B. (1985). Trends of the redistribution of population in Nepal. In L.A. Kosinski \& E. K. Maudood (Eds.), Population redistribution and development in South Asia (pp. 123-138). Dordrecth, D. Reidel Publishing Co.

Young, J. C. (1981). Non-use of physicians: Methodological approaches, policy implications, and the utility of decision models. Social Science \& Medicine, 15 (4), 499-507. http://www.ncbi.nlm.nih.gov 